\title{
Motivasi Berprestasi dan Minat dalam Belajar Mempengaruhi Hasil Belajar Bahasa Indonesia Siswa Kelas V
}

\section{Kadek Ari Indrawan ${ }^{1 *}$, I Ketut Dibia ${ }^{2}$

\author{
1,2,3 Pendidikan Dasar, Universitas Pendidikan Ganesha, Singaraja, Indonesia
}

\section{AR T I C L E I N F O}

Article history:

Received July 14, 2021

Revised July 15, 2021

Accepted October 20, 2021

Available online December 25, 2021

Kata Kunci:

Motivasi Berprestasi, Minat, Hasil Belajar

\section{Keywords:}

Achievement Motivation, Interest, Learning Outcomes

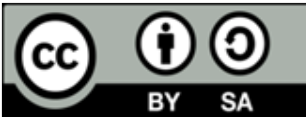

This is an open access article under the CC BY-SA license.

Copyright (ㄷ) 2021 by Author. Published by Universitas Pendidikan Ganesha.

\begin{abstract}
A B S T R A K
Masih banyak siswa yang kesulitan mempelajari Bahasa Indonesia. Hal ini disebabkan karena merasa bosan dalam belajar sehingga berdampak pada hasil belajar siswa yang rendah. Penelitian ini bertujuan untuk menganalisis korelasi antara motivasi berprestasi dan minat belajar dengan hasil belajar Bahasa Indonesia pada siswa kelas $\mathrm{V}$. Jenis penelitian ini yaitu ex post facto dengan menggunakan pendekatan asosiatif kuantitatif. Teknik analisis data pada penelitian ini yaitu analisis deskriptif kualitatif dan kuantitatif. Populasi dalam penelitian ini berjumlah 199 orang siswa. Dalam penelitian ini teknik yang digunakan untuk menentukan sampel adalah Cluster random Sampling yang berjumlah 52 orang siswa. Teknik yang digunakan dalam mengumpulkan data yaitu kuesioner, observasi dan wawancara. Teknik analisis data pada penelitian ini yaitu analisis deskriptif dan inferensial dengan analisis regresi berganda. Hasil penelitian yaitu terdapat korelasi yang signifikan motivasi berprestasi, dan minat belajar siswa terhadap hasil belajar Bahasa Indonesia pada siswa. Jadi motivasi dan minat belajar siswa mempengaruhi hasil belajar siswa. Implikasi penelitian ini yaitu motivasi dan minat siswa yang tinggi akan dapat meningkatkan kemampuan siswa sehingga berdampak pada hasil belajar yang meningkat.
\end{abstract}

\section{A B S T R A C T}

There are still many students who have difficulty learning Indonesian. This is because they feel bored in learning so that it has an impact on low student learning outcomes. This study aims to analyze the correlation between achievement motivation and interest in learning with Indonesian language learning outcomes in fifth-grade students. This type of research is ex post facto using a quantitative associative approach. The data analysis technique in this research is descriptive qualitative and quantitative analysis. The population in this study amounted to 199 students. In this study, the technique used to determine the sample is cluster random sampling, totaling 52 students. The techniques used in collecting data are questionnaires, observations, and interviews. The data analysis technique in this research is descriptive and inferential analysis with multiple regression analysis. The results of the study were that there was a significant correlation between achievement motivation and student interest in learning Indonesian language learning outcomes for students. So students' motivation and interest in learning affect student learning outcomes. The implication of this research is that high student motivation and interest will be able to improve student's abilities so that it has an impact on increasing learning outcomes.

\section{PENDAHULUAN}

Pendidikan merupakan salah satu alat yang dapat mengembangkan kesadaran diri dan sosial seseorang untuk menjadi paduan yang stabil. Pada dasarnnya pendidikan bermaksud membantu siswa untuk memberdayakan seluruh potensi dan menumbuhkembangkan potensi kemanusiaan seseorang ( $\mathrm{F}$. Fitri, 2016; Suryana, 2020; Wulandari et al., 2020). Melalui pendidikan akan membantu anak mengembangkan segala potensi dan mencapai tingkat kedewasaan. Salah satu komponen yang terdapat pada pendidikan yaitu kurikulum (Fitri et al., 2017; Sofyan, 2016). Kurikulum merupaka seperangkat rencana yang berisikan tujuan, isi, serta bahan ajar yang dapat digunakan untuk menyelenggarakan kegiatan belajar (Rahmawati, 2018; Sanjiwana et al., 2015). Salah satu mata pelajaran yang didapatkan oleh anak sekolah dasar yang yaitu Bahasa Indonesia. Bahasa Indonesia memiliki peranan sentral dalam 
perkembangan sosial, intelektual serta emosional siswa yang akan menunjang keberhasilan dalam mempelajari semua bidang lainnya (Irwandi, 2018; Puspayanti et al., 2013; Sari, 2020). Melalui pembelajaran bahasa diharapkan akan membantu siswa untuk mengenal dirinya, budaya, mengemukakan sebuah gagaran, dan menggunakan kemampuan analitis dan imiginatif yang ada pada diri siswa (Joyo, 2018; Martha \& Andini, 2019; Ulfah et al., 2019). Permasalahan yang terjadi saat ini yaitu masih banyak anak yang kesulitan mempelajari Bahasa Indonesia (Dewi et al., 2019; Hidayah, 2015). Hal ini disebabkan karena siswa merasa bosan dalam belajar (Puspitasari, 2018; Susmiati, 2020). Hasil analisis awal menunjukkan permasalahan yakni dalam proses pembelajaran siswa cenderung malas dalam menjawab sebuat soal, serta tidak minat untuk belajar sehingga mengandalkan jawaban dari teman sebangkunya. Siswa memiliki motivasi belajar yang sangat rendah. Siswa menunjukan motivasi belajar yang rendah seperti ribut dikelas, sering keluar kelas, bermain pada saat jam pelajaran. Hal ini berpengaruh pada penguasaan kompetensi Bahasa indonesia siswa menjadi kurang optimal. Hal ini dapat dilihat dari ratarata nilai bahasa indonesia siswa yang masih dibawah KKM yaitu 72,5. Berbagai harapan dan tujuan dari belajar pada kenyataannya belum mampu terealisasikan secara optimal karena dalam penerapanya cukup banyak mengalami kendala di dalam belajar.

Salah satu faktor yang dapat meningkatkan keberhasilan belajar siswa yaitu motivasi. Motivasi intern adalah salah satu faktor yang sangat mendukung keberhasilan pembelajaran (Noervadila \& Misriyati, 2020; Yanthi et al., 2017). Motivasi merupakan tingkah dan sikap dalam bekerja dengan giat untuk mencapai tujuan tertentu dengan penuh rasa tanggung jawab dan disiplin sehingga pekerjaan terlaksana dengan mudah dan mencapai tujuan yang diinginkan yaitu prestasi belajar (Fitriyani \& Sari, 2020; Ningrat et al., 2020). Prestasi dapat dilihat dari usaha yang telah dilalui yang disajikan dalam bentuk nilai ataupun raport pada setiap bidang studi setelah mengalami proses pembelajaran (Insyasiska et al., 2015; Noor \& Wilujeng, 2015). Sehingga dapat dikatakan bahwa motivasi berprestasi adalah segala upaya yang dapat mendorong seseorang untuk belajar dan meraih serta mencapai sesuatu yang diinginkan untuk merah kesuksesan (Ayulina et al., 2020; Fauziah, 2017). Indicator yang dapat menumbuhkan motivasi yaitu keinginan untuk berhasil, kegiatan pembelajaran yang menarik, harapan dan cita-cita masa depan (Risabethe \& Astuti, 2017). Fungsi dan perana motivasi di dalam belajar yaitu menumbuhkan semangat dan minat siswa terhadap materi yang dipelajari. Keberadaan motivasi berprestasi ini dapat mendorong usaha siswa utuk mencapai prestasi belajar siswa (Prayoga, 2019; Sitompul et al., 2017). Motivasi berprestasi dapat menentukan pencapaian tujuan pembelajaran sehingga besarnya motivasi berprestasi akan membantu siswa dalam mencapai kesuksesan. Motivasi belajar ini dapat mencul diakibatkan karena cara guru yang menarik dan disesuaikan dengan kondisi siswa (Afinda et al., 2019; Febriani, 2017; Noervadila et al., 2020). Motivasi berprestasi ini sangat penting untuk mendorong semangat siswa dalam meraih keberhasilan dalam belajar.

Selain motivasi, faktor lainnya yang dapat meningkatkan hasil belajar siswa yaitu minat siswa dalam belajar. Minat adalah ketertarikan khusus terhadap hal atau aktivitas yang dilakukan oleh individu tanpa adanya pengaruh dari luar, sehingga ketertarikan ini akan membuat individu berusaha untuk mendalami serta menekuni hal atau aktivitas yang diminati (Dafit et al., 2020; Salma \& Mudzanatun, 2019). Siswa yang memiliki minat belajar baik akan memiliki kecakapan mengenai cara belajar (Herlina \& Suwatno, 2018b; Sari, 2020). Hal ini yang sangat diperlukan untuk dapat mencapai prestasi belajar. Hasil belajar didapatkan melalui upaya siswa melakukan cara bealjar yang baik. Minat siswa adalah kuncil keberhasilan, setiap pembelajaran yang dilakukan dengan sepenuh hati akan mengantarkan kepada hasil belajar yang baik (Hartuti, 2015; Nurlia et al., 2017; Nursyam, 2019). Oleh karena itu minat siswa harus ditanamkan sejak dini. Dengan semakin tingi motivasi berprestasi dan minat belajar siswa maka akan dapat meningkatkan penguasaan kompetensi Bahasa Indonesia siswa.

Temuan penelitian sebelumnya menyatakan bahwa minat dapat membantu siswa dalam belajar dan membuat siswa tidak merasa bosan dalam belajar (Maesaroh, 2013; Putrayasa, Syahruddin, \& Margunayasa, 2014). Temuan penelitian lainnya juga menyatakan bahwa motivasi dapat memudahkan siswa dalam belajar sehingga berpengaruh pada hasil belajar siswa yang meningkat (Maryani et al., 2017; Suardana \& Simarmata, 2013; Vani, 2016). Penelitian lainnya juga menyatakan bahwa motivasi dan minat belajar sangat mempengaruhi keberhasilan pembelajaran (Fadhilah, 2020; Laras \& Rifai, 2008; Widiyasanti \& Ayriza, 2018). Belum adanya kajian mengenai korelasi antara motivasi berprestasi dan minat belajar dengan hasil belajar Bahasa Indonesia pada siswa kelas V. Kelebihan penelitian ini yaitu penelitian ini akan mengkaji motivasi berprestasi dan minat belajar siswa serta faktor yang mempengaruhinya sehingga dapat membantu guru dan siswa dalam meningkatkan motivasi serta minat belajar. Tujuan penelitian ini yaitu untuk menganalisis korelasi antara motivasi berprestasi dan minat belajar dengan hasil belajar Bahasa Indonesia pada siswa kelas V. Diharapkan motivasi berprestasi dan minat belajar siswa yang tinggi dapat meningkatkan hasil belajar siswa khususnya pada mata pelajaran Bahasa Indonesia. 


\section{METODE}

Jenis penelitian ini yaitu ex post facto. Penelitian ini dilakukan dengan menggunakan pendekatan asosiatif kuantitatif. Pendekatan asosiatif kuantitatif merupakan penelitian berupa angka-angka dan analisis menggunakan statistik. Penelitian ini bertujuan untukmenjelaskan hubungan variabel bebes yaitu motivasi berprestasi dan minat dalam belajar dengan penguasaan kompetensi pengetahuan Bahasa Indonesia (Y). Rancangan penelitian bisa digambarkan seperti pada Gambar 1. Penelitian ini dilaksanakan di Sekolah Dasar Gugus VI Kecamatan Sukasada yang terdiri dari SD Negeri 1 Panji Anom, SD Negeri 2 Panji Anom, SD Negeri 3 Panji Anom SD Negeri 4 Panji Anom SD Negeri 1 Tegalinggah, SD Negeri 2 Tegalinggah, SD Negeri 4 Tegalinggah. Populasi dalam penelitian ini adalah seluruh siswa kelas V SD Gugus VI di Kecamatan Sukasada berjumlah 199 orang siswa. Dalam penelitian ini teknik yang digunakan untuk menentukan sampel adalah Cluster random Sampling. Sampel dari penelitian ini berjumlah 52 orang siswa. Teknik yang digunakan dalam mengumpulkan data yaitu angket atau kuesioner, observasi dan wawancara. Instrument yang digunakan untuk mengumpulkan data yaitu kuesioner. Adapun kisi-kisi instrument tersaji pada Tabel 1 dan 2.

Tabel 1. Kisi-kisi Instrumen Motivasi Berprestasi

\begin{tabular}{ll}
\hline Dimensi & Indikator \\
\hline & Bertanggung jawab \\
& Memperhatikan resiko terhadap tugas \\
Motivasi Berprestasi & Karapan untuk sukses \\
& Mempetisi \\
& Keinginan menjadi yang Terbaik \\
& Suka bekerjasama \\
& Menyukai pekerjaan yang Menantang \\
& Mampu menjadi teladanbagi orang lain \\
& Kekhawatiran akan gagal \\
\hline
\end{tabular}

Tabel 2. Kisi-kisi Instrumen Minat dalam Belajar

\begin{tabular}{ll}
\hline Dimensi & Indikator \\
\hline & Ketaatan terhadap waktu Belajar \\
& Perilaku yang menunjukkan tindakandisiplin pada proses Belajar \\
& Menjaga lingkungan sekolah agar senantiasa indah, aman, dan nyaman \\
& Menghargai peraturan yang dibuat sekolah \\
& Mengetahui batasan-batasan sikap \\
Minat dalam Belajar & Bersungguh-sungguh menjalankan peraturan dengan tanggung jawab \\
\cline { 2 - 3 } & Ketaatan terhadap penggunaan fasilitasbelajar \\
& Menunjukkan sikap beranimenanggung resiko atau konsekuensi dari apa \\
& yang telah dilakukan \\
& Ketaatan terhadap tugas-tugas pelajaran \\
& Ketaatan menggunakanwaktu datang dan pulang \\
&
\end{tabular}

Instrumen yang dikembangkan akan diuji validitas isi dan dilanjutkan dengan uji validitas butir menggunakan rumus korelasi Product Moment Karl Pearson dibantu dengan menggunakan aplikasi Microsoft Excel. Kriteria yang digunakan dalam menentukan derajat reliabelitas suatu tes yaitu dicetuskan oleh seorang ahli yang bernama Guilford. Teknik analisis data pada penelitian ini yaitu analisis deskriptif kualitatif dan kuantitatif. Uji normalitas penelitian ini menggunakan rumus Kolmogorv Smirnov. Analisis data akhir yaitu uji hipotesis dan analisis regresi berganda.

\section{HASIL DAN PEMBAHASAN}

Hasil

Deskripsi data hasil penelitian membahas tiga variabel penelitian yang terdiri dari 2 variabel bebas dan 1 variabel terikat. Penelitian ini menyajikan deskripsi data sebagai berikut: $\mathrm{X}_{1}$ (Motivasi Berprestasi) dan $\mathrm{X}_{2}$ (Minat dalam Belajar) sebagai variabel bebas, sedangkan Y (Hasil Belajar Bahasa Indonesia) sebagai variabel terikat. Deskripsi data penelitian disajikan dalam bentuk grafik. Adapun hasil 
perbedaan perbedaan frekuensi data motivasi berprestasi dan data minat belajar siswa disajikan pada Gambar 1.

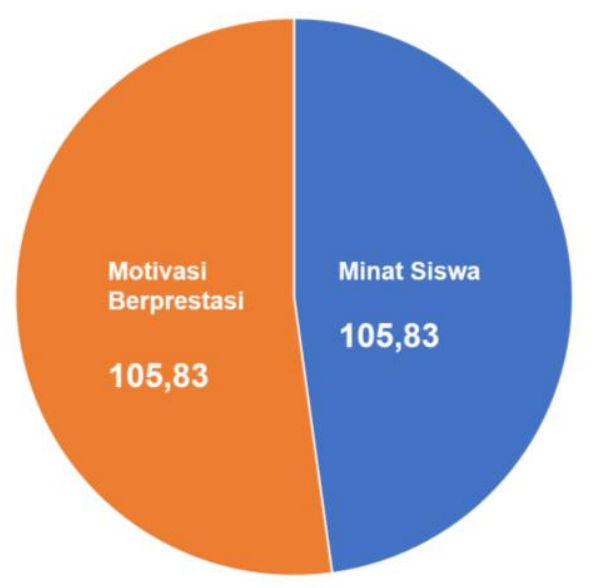

Gambar 2. Hasil Analisis Data Motivasi dan Minat Berprestasi

Dari data angket motivasi berprestasi melalui perhitungan diperoleh rata-rata (mean) diperoleh sebesar 105,83, median sebesar 106,50, dan modus sebesar 103, Standar deviasi 19. Berdasarkan hasil konversi, diketahui rata-rata skor motivasi berprestasi berada diantara 100 - 120, sehingga termasuk dalam kategori baik. Dari data angket minat dalam belajar melalui perhitungan diperoleh rata-rata (mean) diperoleh sebesar 113,38, median sebesar 115,50, dan modus sebesar 120, Standar deviasi sebesar 19. Berdasarkan hasil konversi, diketahui rata-rata skor minat dalam belajar berada diantara 100 - 120 , sehingga termasuk dalam kategori baik. Deskripsi data hasil belajar bahasa Indonesia dapat dipaparkan skor minimum hasil belajar bahasa Indonesia siswa adalah 47, dengan skor maksimum adalah 95. Dari data hasil belajar bahasa Indonesia melalui perhitungan diperoleh rata-rata (mean) diperoleh sebesar 74,58, median sebesar 76, dan modus sebesar 60. Rata-rata nilai hasil belajar bahasa Indonesia adalah 74,58. berdasarkan hasil konversi, diketahui rata-rata nilai hasil belajar bahasa Indonesia berada diantara 70 - 84, sehingga termasuk dalam kategori baik.

Uji prasyaratan analisis dilakukan sebelum uji hipotesis. Uji prasyarat yang dimaksud yaitu: (1) data yang dianalisis harus berdistribusi normal, (2) hubungan antara variabel bebas dan variabel terikat harus linier, (3) tidak terjadi multikolinieritas. Perhitungan dengan menggunakan program SPSS 17.0 for windows. Hasil uji normalitas motivasi berprestasi sebesar 0,200, minat dalam belajar sebesar 0,200, dan hasil belajar bahasa Indonesia sebesar 0,200. Dari hasil pengujian didapatkan bahwa nilai statistik ke tiga variabel pada kolom Kolmogorov-Smirnov lebih besar dari 0,05, maka dapat disimpulkan bahwa semua data dinyatakan normal.Uji linieritas motivasi berprestasi (X1) hasil belajar bahasa Indonesia (Y) yaitu liniearity sebesar 0,000 dan deviation from linearity sebesar 0,165. Berdasarkan analisis yang telah dilakukan, didapatkan signifikansi linearity sebesar $0,000(\mathrm{p}<0,05)$ sehingga motivasi berprestasi dengan hasil belajar bahasa Indonesia memiliki hubungan yang linier. Sedangkan signifikansi deviation from linearity sebesar 0,165 ( $\mathrm{p}>0,05)$ sehingga motivasi berprestasi dengan hasil belajar bahasa Indonesia memiliki hubungan yang berarti. Hasil uji linieritas minat dalam belajar (X2) dengan hasil belajar bahasa Indonesia (Y) yaitu liniearity sebesar 0,000 dan deviation from linearity sebesar 0,155. Berdasarkan analisis yang telah dilakukan, didapatkan signifikansi linearity sebesar $0,000(\mathrm{p}<0,05)$ sehingga minat dalam belajar dengan hasil belajar bahasa Indonesia memiliki hubungan yang linier. Sedangkan signifikansi deviation from linearity sebesar 0,155 ( $p>0,05)$ sehingga minat dalam belajar dengan hasil belajar bahasa Indonesia memiliki hubungan yang berarti. Hasil multikolinieritas motivasi berprestasi dan minat dalam belajar yaitu Tolerance sebesar 0,113 dan VIF sebesar 1,315. asumsi klasik nilai tolerance variabel bebas tidak ada yang kurang dari 10\% dan lebih besar dari 10\%atau 0,1 serta nilai VIF semuanya kurang dari 10 yang berarti tidak terdapat multikolinieritas antar variabel independen dalam model regresi yang digunakan.

Pengujian hipotesis I yaitu Hubungan Motivasi Berprestasi (X1) dengan hasil belajar bahasa Indonesia (Y) dengan melakukan uji-t. Didapatkan thitung $(51.730)>t_{\text {tabel }}(1,684)$, maka H0 ditolak berarti secara statistik ada hubungan yang signifikan antara Motivasi Berprestasi (X) dengan hasil belajar bahasa Indonesia (Y). Dari hasil regresi ini juga dapat diinterprestasikan bahwa ada hubungan yang signifikan antara Motivasi Berprestasi (X1) dengan hasil belajar bahasa Indonesia (Y). Hal ini diperkuat dengan nilai signifikansi 0,000 lebih kecil dari 0,05. Pengujian hipotesis II yaitu Hubungan minat (X2) dengan hasil 
belajar bahasa Indonesia (Y) dengan melakukan uji-t. Didapatkan thitung $(44,002)>$ tabel $(1,684)$, maka H0 ditolak berarti secara statistik ada hubungan yang signifikan antara minat (X) dengan hasil belajar bahasa Indonesia (Y). Dari hasil regresi ini juga dapat diinterprestasikan bahwa ada hubungan yang signifikan antara minat (X2) dengan hasil belajar bahasa Indonesia (Y). Hal ini diperkuat dengan nilai signifikansi 0,000 lebih kecil dari 0,05. Untuk mengetahui Hubungan Motivasi Berprestasi (X1) dan minat dalam Belajar (X2) dengan hasil belajar bahasa Indonesia (Y) digunakan uji $\mathrm{F}$ dan analisis regresi linier berganda. $\mathrm{F}$ hitung $>\mathrm{F}$ tabel yaitu $11,368>3,323$ maka $\mathrm{H}_{\mathrm{o}}$ ditolak dan $\mathrm{H}_{1}$ diterima. Hal ini berarti variabel bebas yang terdiri dari Motivasi Berprestasi (X1) dan Minat dalam Belajar (X2) secara serempak berhubungan signifikan dengan hasil belajar bahasa Indonesia (Y). hal ini juga diperkuat dengan tingkat signifikansi 0,00 yang lebih kecil dari 0,05.

\section{Pembahasan}

Dari penelitian ini diperoleh beberapa temuan penelitian, antara lain temuan pertama, semakin tinggi motivasi berprestasi siswa maka semakin tinggi pula hasil belajar bahasa Indonesia siswa. Siswa yang memiliki motivasi belajar yang tinggi maka akan berdampak pada hasil belajar siswa yang meningkat (Idzhar, 2016; Susmiati, 2020). Hal ini dikarenakan siswa yang memiliki motivasi berprestasi cendrung untuk berusaha meraih keberhasilan dengan melalui proses-proses, seperti selalu bertanggung jawab, memperhatikan resiko terhadap tugas, mempunyai harapan untuk sukses, keinginan menjadi yang terbaik, dan menyukai pekerjaan yang menantang (Astuti et al., 2020; Wuryanti \& Kartowagiran, 2016). Motivasi berprestasi adalah konstruk pisikologis yang mendorong siswa untuk melakukan usaha dengan sebaiknya atas dasar kompetensi yang bertanggung jawab, agar tercapainya hasil belajar yang maksimal berdasarkan setandar keunggulan (Ardhaoui et al., 2021; Moghadam et al., 2020). Motivasi berprestasi sebagai aksi dan perasaan yang berkaitan dengan pencapaian standar keunggulan penyatuan sikap. Siswa yang memiliki motivasi berprestasi yang kuat cenderung percaya diri, bertanggung jawab dengan tindakannya, memperhitungkan resiko, membuat perencanaan dengan bijaksana, menghemat waktu (Kim et al., 2020; Parker et al., 2021). Faktor motivasi diartikan suatu sikap (attitude), situasi kerja (situation) di lingkungan organisasinya di dalam dunia belajar motivasi menempati unsur terpenting yang harus dimiliki siswa (Noervadila \& Misriyati, 2020; Winursiti, 2017; Yanthi et al., 2017).

Temuan kedua, minat dalam belajar dengan hasil belajar bahasa Indonesia Kelas V SD Gugus VI Kecamatan Sukasada Tahun Pelajaran 2020/2021. Minat belajar adalah kecenderungan yang tetap untuk memperhatikan dan mengenang beberapa kegiatan dan kegiatan tersebut termasuk belajar (Butler \& Shibaz, 2014; Ya-hsunTsai et al., 2018). Faktor minat belajar ini sangat menentukan hasil belajar siswa karena minat ini akan menyebabkan ketertarikan secara khusus terhadap suatu hal atau aktifitas yang ada dalam diri seseorang atau individu tanpa ada pengaruh dari luar, dimana ketertarikan ini akan membuat individu tersebut berusaha untuk mendalami atau menekuni hal atau aktifitas yang dia minati (Mulyantini et al., 2019; Putrayasa, Syahruddin, \& Margunayasa, 2014). Minat yang dimiliki siswa terhadap materi pembelajaran tertentu membuat siswa bersemangat dalam belajar. Hal ini juga menyebabkan pembelajaran akan menjadi menyenangkan dan siswa juga akan termotivasi untuk dapat mencapai hasil belajar yang maksimal (Herlina \& Suwatno, 2018a; Putrayasa, Syahruddin, \& Mergunayasa, 2014).

Temuan ketiga, ditemukan korelasi yang signifikan yang berarti semakin tinggi motivasi berprestasi dan minat dalam belajar siswa maka semakin tinggi pula hasil belajar bahasa Indonesia siswa. Hal ini dikarenakan siswa yang memiliki motivasi berprestasi cendrung untuk berusaha meraih keberhasilan dengan melalui proses-proses, seperti selalu bertanggung jawab, memperhatikan resiko terhadap tugas, mempunyai harapan untuk sukses, keinginan menjadi yang terbaik, dan menyukai pekerjaan yang menantang (Abdelrahman, 2020; Kulakow, 2020). Selain motivasi berprestasi, disiplin dalam belajar juga berperan dalam meningkatkan hasil belajar (Anggraini et al., 2018; Fasikhah, 2019; Prayoga, 2019). Hal ini dikarenakan siswa yang memiliki minat dalam belajar cendrung berperan penting dalam kehidupan peserta didik dan mempunyai dampak yang besar terhadap sikap dan perilaku siswa (J. Fitri, 2019; Herlina \& Suwatno, 2018a). Siswa yang memiliki minat belajar besar terhadap suatau mata pelajaran akan berusaha lebih giat dibandingkan mereka yang kurang atau tidak berminat (Maesaroh, 2013; Ningsih et al., 2018; Qusyairi \& Jannati, 2018).

Temuan penelitian sebelumnya menyatakan bahwa motivasi belajar akan berdampak pada hasil belajar siswa (Hsieh et al., 2021; Partovi \& Razavi, 2019). Temuan penelitian lainnya juga menyatakan bahwa minat belajar memiliki peranan yang sangat penting dalam meningkatkan hasil belajar siswa (Fauziah, 2017; Herlina \& Suwatno, 2018b; Tafonao, 2018). Dapat disimpulkan bahwa minat dan motivasi belajar yang tiggi akan meningkatkan hasil belajar siswa. Kelebihan dari penelitian ini yaitu penelitian mengungkapkan bahwa motivasi berprestasi dan minat belajar siswa serta faktor yang mempengaruhinya sehingga dapat membantu guru dan siswa dalam meningkatkan motivasi serta minat belajar. Penelitian ini berkontribusi pada peningkatan semangat serta hasil belajar siswa sehingga berdampak pada hasil belajar siswa. Keterbatasan penelitian ini yaitu banyak faktor yang mempengaruhi hasil belajar siswa 
tetapi penelitian ini hanya mengkaji motivasi dan minat belajar siswa terhadap hasil belajar siswa. Implikasi penelitian ini yaitu motivasi dan minat siswa yang tinggi akan dapat meningkatkan kemampuan siswa sehingga berdampak pada hasil belajar yang meningkat.

\section{SIMPULAN}

Terdapat hubungan yang signifikan motivasi berprestasi dengan hasil belajar bahasa Indonesia. Selain itu, adanya hubungan yang signifikan minat dalam belajar dengan hasil belajar bahasa Indonesia. Terdapat hubungan yang signifikan antara motivasi berprestasi dan minat dalam belajar dengan hasil belajar bahasa Indonesia. Disimpulkan bahwa motivasi dan minat belajar siswa mempengaruhi hasil belajar siswa. Direkomendasikan kepada guru untuk dapat meningkatkan motivasi serta minat siswa dalam belajar sehingga akan berdampak pada hasil belajar siswa yan meningkat.

\section{DAFTAR PUSTAKA}

Abdelrahman, R. M. (2020). Metacognitive awareness and academic motivation and their impact on academic achievement of Ajman University students. Heliyon, 6(9). https://doi.org/10.1016/j.heliyon.2020.e04192.

Afinda, Aisyah, \& Wijayanti. (2019). Cooperative-STAD Dengan Word Square: Dampaknya Terhadap Motivasi Dan Hasil Belajar Siswa. JIPVA (Jurnal Pendidikan Ipa Veteran), 3(1), 17 - 27. https://doi.org/10.31331/jipva.v3i1.773.

Anggraini, Y., Patmanthara, S., \& Purnomo, P. (2018). Pengaruh Lingkungan Belajar Dan Disiplin Belajar Terhadap Hasil Belajar Kompetensi Keahlian Elektronika Industri Di Sekolah Menengah Kejuruan. Jurnal Pendidikan: Teori , Penelitian Dan Pengembangan, 2(12). http://dx.doi.org/10.17977/jptpp.v2i12.10316.

Ardhaoui, K., Lemos, M. S., \& Silva, S. (2021). Effects of new teaching approaches on motivation and achievement in higher education applied chemistry courses: A case study in Tunisia. Education for Chemical Engineers, 36. /https://doi.org/10.1016/j.ece.2021.05.004.

Astuti, J., Novita, M., \& Ismail, M. S. (2020). Peningkatan Motivasi Belajar Menggunakan Contextual Teaching and Learning di Madrasah Ibtidaiyah Swasta Raudhatul Mujawwidin Tebo. Jurnal Educative, 5(1). http://dx.doi.org/10.30983/educative.v5i1.1630.

Ayulina, Ngurah, G., \& Agustika, S. (2020). Kontribusi Konsep Diri dan Motivasi Belajar Terhadap Kompetensi Pengetahuan Matematika. Mimbar PGSD Undiksha, 8(1), 70-79. /http://dx.doi.org/10.23887/jjpgsd.v8i1.24580.

Butler, R., \& Shibaz, L. (2014). Striving to connect and striving to learn: Influences of relational and mastery goals for teaching on teacher behaviors and student interest and help seeking. International Journal of Educational Researc, 65. https://doi.org/10.1016/j.ijer.2013.09.006.

Dafit, F., Mustika, D., \& Melihayatri, N. (2020). Pengaruh Program Pojok Literasi Terhadap Minat Baca Mahasiswa. Jurnal Basicedu, 4(1). /https://doi.org/10.31004/basicedu.v4i1.307.

Dewi, N. N. K., Kristiantari, M. . R., \& Ganing, N. N. (2019). Pengaruh Model Pembelajaran Picture And Picture Berbantuan Media Visual Terhadap Keterampilan Menulis Bahasa Indonesia. Journal of Education Technology, 3(4). http://dx.doi.org/10.23887/jet.v3i4.22364.

Fadhilah, N. (2020). Hubungan Antara Daya Ketahanmalangan Dan Minat Belajar Dengan Hasil Belajar Matematika Siswa. Jurnal Pendidikan Dasar, 12(1), 37-47. https://doi.org/10.17509/eh.v12i1.17687.

Fasikhah. (2019). Hubungan Kebiasaan dan Disiplin Belajar dengan Hasil Belajar IPS. Scientific Journals, 1(3), 55-64. https://doi.org/https://doi.org/10.15294/jlj.v9i1.39136.

Fauziah, A. (2017). Hubungan Antara Motivasi Belajar Dengan Minat Belajar Siswa Kelas IV SDN Poris Gaga 05 Kota Tanggerang. Jurnal Pendidikan Sekolah Dasar, 4(1). http://dx.doi.org/10.12928/jpsd.v4i2.9594.

Febriani, C. (2017). Pengaruh Media Video terhadap Motivasi Belajar dan Hasil Belajar Kognitif Pembelajaran IPA Kelas V Sekolah Dasar. Jurnal Prima Edukasia, 5(1), 11-21. https://doi.org/10.21831/jpe.v5i1.8461.

Fitri, F. (2016). Peningkatan Kemandirian Mahasiswa Pendidikan Fisika Pada Mata Kuliah Mekanika Melalui Metode Reciprocal Teaching. Jurnal Pendidikan Fisika., 4(1). /http://dx.doi.org/10.24127/jpf.v4i1.391.

Fitri, J. (2019). Minat Baca Dan Kebiasaan Mencontek Dalam Hasil Belajar Memahami Teks Diskusi Siswa Kelas IX SMP N 1 Pariaman. Jurnal Bahasa Indonesia, Sastra, Dan Pengajarannya, 5(1), 31-38. http://dx.doi.org/10.26740/jpi.v5n1.p31-38. 
Fitri, Saparahayuningsih, \& Agustriana. (2017). Perencanaan Pembelajaran Kurikulum 2013 Pendidikan Anak Usia Dini. Jurnal Ilmiah Potensia, 2(1). https://doi.org/10.33369/jip.2.1.1-13.

Fitriyani, \& Sari. (2020). Motivasi Belajar Mahasiswa Pada Pembelajaran Daring Selama Pandemik Covid19. Jurnal Kependidikan: Jurnal Hasil Penelitian Dan Kajian Kepustakaan Di Bidang Pendidikan, Pengajaran, Dan Pembelajaran, 6(2), 165-175. https://doi.org/10.33394/jk.v6i2.2654.

Hartuti. (2015). Peran konsep diri, minat dan kebiasaan belajar peserta didik terhadap prestasi belajar fisika. Formatif: Jurnal Ilmiah Pendidikan MIPA, 5(2). http://dx.doi.org/10.30998/formatif.v5i2.329.

Herlina, L., \& Suwatno, S. (2018a). Kecerdasan Intelektual Dan Minat Belajar Sebagai Determinan Prestasi Belajar Siswa. Jurnal Pendidikan Manajemen Perkantoran, 3(2). https://doi.org/10.17509/jpm.v3i2.11771.

Herlina, \& Suwatno. (2018b). Kecerdasan Intelektual Dan Minat Belajar Sebagai Determinan Prestasi Belajar Siswa. Jurnal Pendidikan Manajemen Perkantoran, 3(2). https://doi.org/10.17509/jpm.v3i2.11771.

Hidayah, N. (2015). Penanaman Nilai-Nilai Karakter Dalam Pembelajaran Bahasa Indonesia Di Sekolah Dasar. TERAMPIL: Jurnal Pendidikan dan Pembelajaran Dasar, 2(2), 190204.https://doi.org/10.24042/terampil.v2i2.1291. Jurnal Pendidikan Dan Pembelajaran Dasar, 2(2), 190-204. https://doi.org/10.24042/terampil.v2i2.1291.

Hsieh, T., Simpkins, S. D., \& Eccles, J. S. (2021). Gender by racial/ethnic intersectionality in the patterns of Adolescents' math motivation and their math achievement and engagement. Contemporary Educational Psychology, 66. https://doi.org/10.1016/j.cedpsych.2021.101974.

Idzhar, A. (2016). Peranan Guru Dalam Meningkatkan Motivasi Belajar Siswa. Jurnal Office, 2(2), 222-228. /https://doi.org/10.26858/jo.v2i2.2956.

Insyasiska, Zubaidah, \& Susilo. (2015). Pengaruh Project Based Learning terhadap Motivasi Belajar, Kreativitas, Kemampuan Berpikir Kritis, dan Kemampuan Kognitif Siswa pada Pembelajaran Biologi. Jurnal Pendidikan Biologi, 7(1), 9-21. http://dx.doi.org/10.17977/um052v7i1p9-21.

Irwandi. (2018). Penerapan Model Kooperatif Teknik Paired Story Telling Untuk Meningkatkan Kemampuan Bercerita Siswa Kelas V Pada Pembelajaran Bahasa Indonesia Min Mesjid Raya Banda Aceh. Piornir: Jurnal Pendidikan, 7(1). http://dx.doi.org/10.22373/pjp.v7i1.3320.

Joyo, A. (2018). Gerakan Literasi Dalam Pembelajaran Bahasa Indonesia Berbasis Kearifan Lokal Menuju Siswa Berkarakter. Jurnal Kajian Bahasa, Sastra Dan Pengajaran (KIBASP), 1(2). https://doi.org/10.31539/kibasp.v1i2.193.

Kim, Y., Mok, S. Y., \& Seidel, T. (2020). Parental influences on immigrant students' achievement-related motivation and achievement: A meta-analysis. Educational Research, 30. https://doi.org/10.1016/j.edurev.2020.100327.

Kulakow, S. (2020). Academic self-concept and achievement motivation among adolescent students in different learning environments: Does competence-support matter? Learning and Motivation, 70. https://doi.org/10.1016/j.lmot.2020.101632.

Laras, S. A., \& Rifai, A. (2008). Pengaruh Minat Dan Motivasi Belajar Terhadap Hasil Belajar Peserta Didik Di Bbplk Semarang. Jurnal E-Plus, 4(2). http://dx.doi.org/10.30870/e-plus.v4i2.7307.

Maesaroh, S. (2013). Peranan Metode Pembelajaran Terhadap Minat Dan Prestasi Belajar Pendidikan Agama Islam. Jurnal Kependidikan, 1(1). https://doi.org/10.24090/jk.v1i1.536.

Martha, nia ulfa, \& Andini, novita pri. (2019). Pengembangan Bahan Ajar Mata Pelajaran Bahasa Indonesia Berbasis Cerita Rakyat Kabupaten Banjarnegara. Jurnal Inovasi Pembelajaran, 5(2). https://doi.org/10.22219/jinop.v5i2.9992.

Maryani, N., Ichsan, M., \& Khairunnisa. (2017). Signifikansi Metode Guide Reading Terhadap Motivasi Belajar Siswa Dalam Teori Membaca Nyaring Guide Reading Method On Students ' Learning Motivation In Reading Loudly Lesson. Didaktika Tauhidi: Jurnal Pendidikan Guru Sekolah Dasar, 4(2), 126-139. http://dx.doi.org/10.30997/dt.v4i2.924.

Moghadam, M. T., Abbasi, E., \& Khoshnodifar, Z. (2020). Students' academic burnout in Iranian agricultural higher education system: the mediating role of achievement motivation. Heliyon, 6(9). https://doi.org/10.1016/j.heliyon.2020.e04960.

Mulyantini, N. L. D., Suranata, K., \& Margunayasa, I. G. (2019). Pengaruh Model Pembelajaran Two Stay Two Stray Terhadap Minat Belajar Ipa Siswa Kelas IV SD. MIMBAR PGSD Undiksha, 7(1). http://dx.doi.org/10.23887/jjpgsd.v7i1.17023.

Ningrat, S. P., Agung, A. A. G., \& Yudana, I. M. (2020). Kontribusi Etos Kerja, Motivasi Kerja, Disiplin Kerja dan Supervisi Akademik Terhadap Kinerja Guru Sd Gugus VII Kecamatan Mengwi. Jurnal Administrasi Pendidikan Indonesia, 3(1), 54-63. https://doi.org/10.23887/japi.v11i1.3169.

Ningsih, N. L. P. R., Darsana, I. W., \& Abadi, I. B. G. S. (2018). Korelasi Antara Minat Belajar dengan Hasil 
Belajar IPS. Mimbar PGSD Undiksha, 6(3), 202-209. https://doi.org/10.23887/jjpgsd.v6i3.21097. Noervadila, Irma, \& Misriyati. (2020). Pengaruh Gaya Belajar Dan Motivasi Belajar Terhadap Hasil Belajar Siswa Pada Mata Pelajaran Matematika Kelas X Ips Semester Genap Di Ma Fathus Salafi Tahun Pelajaran 2019/2020. Jurnal IKA: Ikatan Alumni PGSD UNARS, 8(1), 48-56. https://doi.org/10.36841/pgsdunars.v8i1.582.

Noervadila, \& Misriyati. (2020). Pengaruh Gaya Belajar Dan Motivasi Belajar Terhadap Hasil Belajar Siswa Pada Mata Pelajaran Matematika Kelas X IPS Semester Genap Di MA Fathus Salafi Tahun Pelajaran 2019/2020. Jurnal IKA: Ikatan Alumnus PGSD UNARS, 8(1). https://doi.org/10.36841/pgsdunars.v8i1.582.

Noor, F. M., \& Wilujeng, I. (2015). Pengembangan Ssp Fisika Berbasis Pendekatan Ctl Untuk Meningkatkan Keterampilan Proses Sains Dan Motivasi Belajar. Jurnal Inovasi Pendidikan Fisika, 1(1). https://doi.org/10.21831/jipi.v1i1.4534.

Nurlia, Hala, Muchtar, Jumadi, \& Taiyeb. (2017). Hubungan Antara Gaya Belajar, Kemandirian Belajar, Dan Minat Belajar Dengan Hasil Belajar Biologi Siswa. Jurnal Pendidikan Biologi, 6(2). https://doi.org/10.24114/jpb.v6i2.6552.

Nursyam, A. (2019). Peningkatan Minat Belajar Siswa Melalui Media Pembelajaran Berbasis Teknologi Informasi. Jurnal Penelitian Hukum Dan Pendidikan, 18(1), 811-819. http://dx.doi.org/10.30863/ekspose.v18i1.371.

Parker, P. C., Perry, R. P., Hamm, J. M., Chipperfield, J. G., Dryden, R. P., \& Daniels, L. M. (2021). A motivation perspective on achievement appraisals, emotions, and performance in an online learning environment. International Journal of Educational Research, 108. https://doi.org/10.1016/j.ijer.2021.101772.

Partovi, T., \& Razavi, M. R. (2019). The effect of game-based learning on academic achievement motivation of elementary school studentsNo Title. Learning and Motivation, 68. https://doi.org/10.1016/j.lmot.2019.101592.

Pasek, N. (2018). Determinasi Sikap Guru terhadap Profesinya, Konsep Diri, dan Iklim Kerja Sekolah terhadap Kinerja Guru Sekolah Dasar. Jurnal Penelitian Dan Pengembangan Sains Dan Humaniora, 1(1). https://doi.org/10.23887/jppsh.v1i1.12926.

Prayoga, A. (2019). Pengaruh kegiatan awal pembelajaran, disiplin belajar dan motivasi belajar terhadap prestasi belajar. Jurnal Ilmiah Pendidikan Dan Pembelajaran, 3(1), 53-64. http://dx.doi.org/10.23887/jipp.v3i1.17110.

Puspayanti, I. G. A. R., Darsana, I. W., \& Ganing, N. N. (2013). Pengaruh Pendekatan Savi Terhadap Keterampilan Menyimak Pada Mata Pelajaran Bahasa Indonesia Gugus Letkol Wisnu Kecamatan Denpasar Utara. Mimbar PGSD Undiksha, 1(1). http://dx.doi.org/10.23887/jjpgsd.v1i1.1256.

Puspitasari. (2018). Metode Pembelajaran Bermain Peran Pada Pembelajaran Bahasa Indonesia. Jurnal Cakrawala Pendas, I(1), 55-64. http://dx.doi.org/10.31949/jcp.v1i1.347.

Putrayasa, I. M., Syahruddin, \& Mergunayasa, I. G. (2014). Pengaruh Model Pembelajaran Discovery Learning Dan Minat Belajar Terhadap Hasil Belajar Ipa Siswa. Jurnal Mimbar PGSD Universitas Pendidikan Ganesha, 2(1). http://dx.doi.org/10.23887/jjpgsd.v2i1.3087.

Putrayasa, I. M., Syahruddin, S. P., \& Margunayasa, I. G. (2014). Pengaruh Model Pembelajaran Discovery Learning dan Minat Belajar Terhadap Hasil Belajar IPA Siswa. Jurnal Mimbar PGSD Universitas Pendidikan Ganesha, 2(1). http://dx.doi.org/10.23887/jjpgsd.v2i1.3087.

Qusyairi, L. A. H., \& Jannati. (2018). Pengaruh Model Cooperative Learning Tipe Inside-Outside Circle (IOC) terhadap Prestasi Belajar dengan Memperhatikan Minat Belajar Matematika. Palapa: Jurnal Studi Keislaman Dan Ilmu Pendidikan, 6(1). https://doi.org/10.36088/palapa.v6i1.57.

Rahmawati, A. (2018). Identifikasi Masalah yang Dihadapi Guru dalam Penerapan Kurikulum 2013. Indonesian Journal of Primary Education, 2(1), 114-123. https://doi.org/10.17509/ijpe.v2i1.14227.

Risabethe, \& Astuti. (2017). Pengembangan Media Pembelajaran Untuk Meningkatkan Motivasi Belajar Dan Karakter Semangat Kebangsaan Siswa Kelas V SD. Jurnal Pendidikan Karakter, 1. /https://doi.org/10.21831/jpk.v7i1.15498.

Salma, \& Mudzanatun. (2019). Analisis Gerakan Literasi Sekolah Terhadap Minat Baca Siswa Siswa $\begin{array}{lllll}\text { Sekolah Dasar. Mimbar } \quad \text { PGSD } & \text { Undiksha, } & \text { 7(2), }\end{array}$ http://dx.doi.org/10.23887/jjpgsd.v7i2.17555.

Sanjiwana, P. P. C. M., Pudjawan, K., \& Margunayasa, I. G. (2015). Analisis sikap sosial siswa kelas V pada pembelajaran dengan kurikulum 2013. Mimbar PGSD Universitas Pendidikan Ganesha, 3(1). http://dx.doi.org/10.23887/jjpgsd.v3i1.5631.

Sari, P. A. P. (2020). Hubungan Literasi Baca Tulis Dan Minat Membaca Dengan Hasil Belajar Bahasa Indonesia. Journal for Lesson and Learning Studies, 3(1), 141-152. 
http: //dx.doi.org/10.23887/jlls.v3i1.24324.g14714.

Sitompul, Setiawan, \& Purba. (2017). Pengaruh Media Pembelajaran Dan Motivasi Belajar Terhadap Hasil Belajar Desain Sistem Instruksional Pendekatan Tpack. Jurnal Teknologi Informasi Dan Komunikasi Dalam Pendidikan, 4(2), 141-146. https://doi.org/10.24114/jtikp.v4i2.8761.

Sofyan. (2016). Pembelajaran Problem Based Learning dalam Implementasi Kurikulum 2013 di SMK. Jurnal Pendidikan Vokasi, 6(3), 260-271. https://doi.org/10.21831/jpv.v6i3.11275.

Suardana, \& Simarmata. (2013). Hubungan Antara Motivasi Belajar dan Kecemasan pada Siswa Kelas Vi Sekolah Dasar di Denpasar Menjelang Ujian Nasional. Jurnal Psikologi Udayana, 1(1). https://doi.org/10.24843/JPU.2013.v01.i01.p20.

Suryana. (2020). Permasalahan Mutu Pendidikan Dalam Perspektif Pembangunan Indonesia. Jurnal Edukasi, 14(1). https://doi.org/10.15294/edukasi.v14i1.971.

Susmiati, E. (2020). Meningkatkan Motivasi Belajar Bahasa Indonesia Melalui Penerapan Model Discovery Learning dan Media Video Dalam Kondisi Pandemi Covide-19 bagi Siswa SMPN 2 Gangga. Jurnal Penelitian Dan Pengembangan Pendidikan, https://doi.org/https://doi.org/10.33394/jp.v7i3.2732.

Tafonao, T. (2018). Peranan Media Pembelajaran Dalam Meningkatkan Minat Belajar Mahasiswa. Jurnal Komunikasi Pendidikan, 2(2), 103. https://doi.org/10.32585/jkp.v2i2.113.

Ulfah, D., Garim, I., \& Sultan, S. (2019). Bias Gender Dalam Buku Teks Pelajaran Bahasa Indonesia Sekolah Menengah Atas. RETORIKA: Jurnal Bahasa, Sastra, Dan Pengajarannya, 12(2). https://doi.org/10.26858/retorika.v12i2.8935.

Vani, S. (2016). Analisis Pengaruh Motivasi Belajar terhadap Hasil Belajar Ekonomi Siswa Kelas X SMA $\begin{array}{lllll}\text { Negeri } & 5 & \text { Padang. } & \text { Economica, }\end{array}$ https://dx.doi.org/10.22202/economica.2016.v4.i2.669.

Widiyasanti, M., \& Ayriza, Y. (2018). Pengembangan Media Video Animasi untuk Meningkatkan Motivasi Belajar dan Karakter Tanggung Jawab Siswa Kelas V. Jurnal Pendidikan Karakter, 8(1). https://doi.org/10.21831/jpk.v8i1.21489.

Winursiti. (2017). Penerapan Model Problem Based Learning Berbantuan Reinforcement Simbolik Untuk Meningkatkan Motivasi Dan Hasil Belajar Matematika Siswa Kelas IVB di SD Lab Undiksha. Jurnal Ilmiah Sekolah Dasar, 17(2), 270-275. http://dx.doi.org/10.23887/jisd.v1i4.12120.

Wulandari, N. P. R., Dantes, N., \& Antara, P. A. (2020). Pendekatan Pendidikan Matematika Realistik Berbasis Open Ended Terhadap Kemampuan Pemecahan Masalah Matematika Siswa. Jurnal Ilmiah Sekolah Dasar Universitas Pendidikan Ganesha, 4(2), 153-164. http://dx.doi.org/10.23887/jisd.v4i2.25103.

Wuryanti, U., \& Kartowagiran, B. (2016). Pengembangan Media Video Animasi untuk Meningkatkan Motivasi Belajar dan Karakter Kerja Keras Siswa Sekolah Dasar. Jurnal Pendidikan Karakter, 6(2). https: //doi.org/ 10.21831/jpk.v6i2.12055.

Ya-hsunTsai, Lin, C., Hong, J., \& Kai-hsin Tai. (2018). The effects of metacognition on online learning interest and continuance to learn with MOOCs. Computers \& Education, 121, 18-29. https://doi.org/10.1016/j.compedu.2018.02.011.

Yanthi, Japa, \& Tegeh. (2017). Pengaruh Model Pembelajaran Kooperatif Tipe NHT DAN Motivasi Belajar Terhadap Hasil Belajar IPA. MIMBAR PGSD Undiksha, 5(2), 1-10. http://dx.doi.org/10.23887/jjpgsd.v5i2.10914. 